\begin{tabular}{|c|}
\hline Towards a Theory of the Reform of the Common Agricultural Policy \\
\hline Adrian Kay \\
\hline 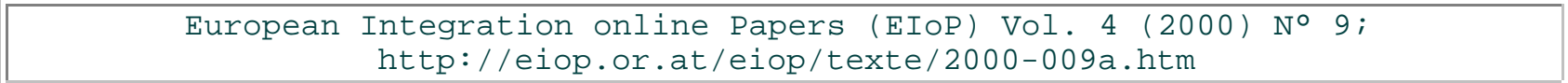 \\
\hline Date of publication in the EIOP: 7.7.2000 \\
\hline 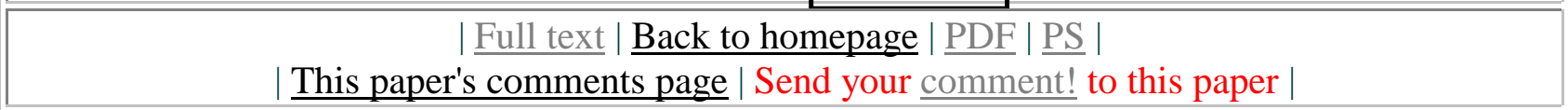 \\
\hline Keywords \\
\hline $\begin{array}{c}\text { agriculture policy, GATT, agenda 2000. neo-institutionalism, interest representation, economics, } \\
\text { political science }\end{array}$ \\
\hline Abstract \\
\hline $\begin{array}{l}\text { This paper sets up two competing frameworks to assess the evidence of the CAP reforms of the } \\
\text { 1980s and 1990s. The two frameworks differ in the degree of prominence given to interest groups } \\
\text { in affecting CAP decisions. The paper concludes that the most important mechanism behind CAP } \\
\text { reforms is the interaction of EU institutions and member state governments. Interest groups, at } \\
\text { national or EU-level, have limited influence on the reform process. The paper does not claim to } \\
\text { have developed a new theory of CAP reform but rather aims to suggest a direction for the } \\
\text { development of a high content theory that is able to account for the differences between episodes of } \\
\text { CAP reform as well as the similarities. }\end{array}$ \\
\hline Kurzfassung \\
\hline $\begin{array}{l}\text { Dieses Papier stellt zwei konkurrierende Rahmen für die Analyse der Reform der Gemeinsamen } \\
\text { Agrarpolitik (GAP) der 80er und 90er Jahre dar. Die beiden Rahmen unterscheiden sich darin, } \\
\text { wieviel Einfluß den Interessensgruppen auf die GAP-Entscheidungen beigemessen wird. Der } \\
\text { Beitrag kommt zu dem Schluß, daß der wichtigste Mechanismus innerhalb der Reformen die } \\
\text { Interaktion der EU-Institutionen mit den mitgliedstaatlichen Regierungen ist. Das Papier versucht } \\
\text { nicht die Entwicklung einer neuen Theorie der GAP-Reform, sondern zielt vielmehr darauf ab, die } \\
\text { Richtung für die Entwicklung einer mächtigen Theorie aufzuzeigen, die in der Lage wäre, die } \\
\text { Unterschiede ebenso wie die Gemeinsamkeiten der verschiedenen Reformabschnitte zu erklären. }\end{array}$ \\
\hline The author \\
\hline $\begin{array}{l}\text { Dr. Adrian Kay is a lecturer in economics in the Business School at the University of Glamorgan. } \\
\text { He studied Philosophy, Politics and Economics at Oxford University and has a PhD in Applied } \\
\text { Economics from the University of Nottingham; email: akay@glam.ac.uk }\end{array}$ \\
\hline
\end{tabular}




\section{Towards a Theory of the Reform of the Common Agricultural Policy $(*)$}

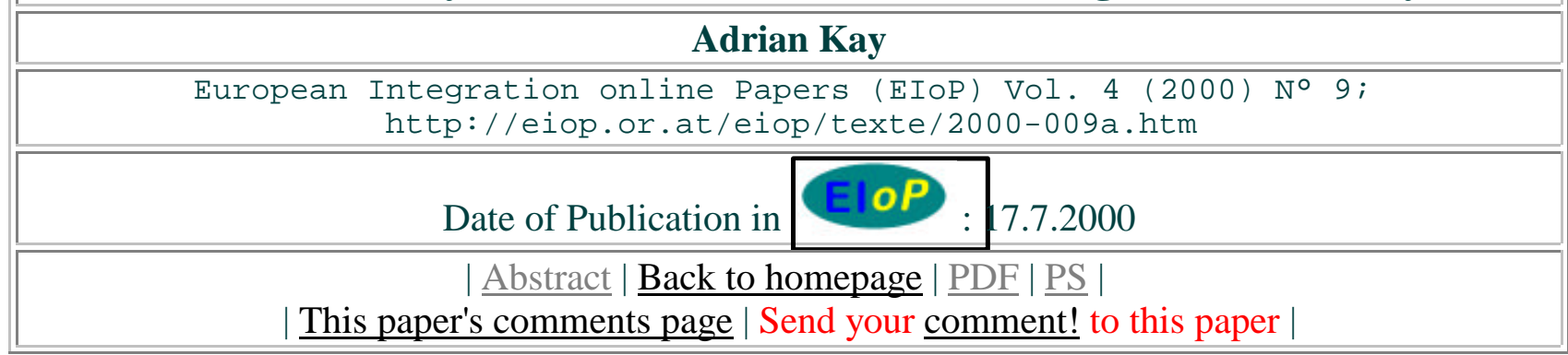

\section{Contents:}

- I. Introduction

- II. Interest groups framework versus institutions framework

- III. The interest groups framework

- IV. The institutions framework

- $\underline{\text { V. Conclusion }}$

- $\underline{\text { References }}$

\section{Introduction}

The agreement to reform the CAP on 11 March 1999 was the fourth reform in 15 years. This paper aims to contribute to the development of a theory of CAP reform by considering two rival groups of theories or frameworks; the institutions framework and the interest groups framework. The term framework is used advisedly to refer to a set of theories that are linked by common assumptions, themes or concepts. It is a useful term here because the current literature does not offer a well-developed, high content theory of CAP reform. The paper does not claim to have developed a new theory of CAP reform but rather aims to suggest a direction for the development of a theory that is able to account for the differences between episodes of CAP reform as well as the similarities.

The paper uses the following methodology. The existing literature on theories of agricultural support and EU-level policy-making is reviewed for each framework. In addition, there is a brief survey of the evidence of previous CAP reforms in terms of fieldwork interviews reported, primary documents and contemporary commentaries. From these observables, the paper uses the literature to help make inferences about the unobservable mechanisms that might explain a CAP reform. Such unobservables include power, influence, the role of the timing and environment of decisions as well as the preferences of both individuals and institutional actors involved in a CAP reform. A process of inference to the best explanation is used to appraise the frameworks, or as Kinach (1996) states it, the case of selecting the framework 'that explains a greater range of facts than its rival'. This paper holds that such abductive reasoning, as opposed to a strict hypothetico-deductive method of theory-testing, is justified in this case because of the limited range of CAP reform evidence and the underdeveloped nature of existing theories of CAP reform.

Section II sets out the basic differences between the two frameworks. Section III uses the methodology above to develop interest group theories of CAP reform. Section IV does the same for institutions approaches to CAP reform. Section V contains the paper's three broad conclusions. First, there is little evidence from of interest group influence at an EU-level on either the initiation or outcome of the CAP reform process. Second, at a national level there is some evidence that the 
influence and power of national farm interest groups is declining in key member states. Third, the interaction of different EU institutions and member state governments is the main dynamic behind a reform process; this is where reforms are conceived, constructed and enacted.

\section{Interest groups framework versus institutions framework}

Egdell and Thomson (1999, p.130) observe that the CAP will '...continue to be a key battleground for the interrelationships between the government and non-government organizations in the agricultural, environmental and rural development policy arenas.' Smith (1993) provides a typology of these interrelationships, running from closed, stable policy communities (Richardson and Jordan, 1979; Mazey and Richardson, 1993) which have been applied to the EU generally and agriculture in particular (Grant, 1993; Smith, 1990) to open, unstable issue networks (Marsh and Rhodes, 1992.

The two frameworks presented in this paper differ in their degree of emphasis on the ability of interest groups to affect decisions to reform the CAP. The interest groups framework gives a prominent role to interest groups in the CAP reform process. It is based on the claim that the Commission or individual member states are 'heavily influenced' (Edgell and Thomson (1999, p.122) by the lobbying of interest groups. The institution framework is based on the premise that the actors with the greatest influence in the CAP decision-making process are the institutions directly involved, the Commission and the 15 member states in the Council of Agricultural Ministers (CoAM).

\section{The interest groups framework}

There are two sources for the group of theories that form the interest groups framework. First, there is a literature of theoretical and abstract work on interest groups that has been applied to the CAP. Secondly, the history of the development of state support for agriculture at an EU and member state level has been written in terms of the political strength of farm interest groups.

Agricultural policy is mentioned as an example of successful interest group activity in the following theoretical works: Olson (1965) argued that farm interest groups had solved the collective action problem posed by the incentive to free-ride; Stigler (1975) and Becker (1983) described farm groups as successful in the political market for rent-creating interventions by government; Hirschman (1970) used farm interest groups to illustrate his concept of 'exit and voice'. In all these works, the farm lobby is cited as an example of a well-organised, disciplined group able to exert political influence. Brooks (1996) provides a survey of the formal political economy models of agricultural policy developed within the interest groups framework.

This literature is divided on the relative importance of interest groups and individual voters in analysing rent-seeking behaviour. In particular, Brooks $(1995,1996)$ and De Gorter and Swinnen $(1994,1995)$ have disagreed on the issue of whether voters are rationally ignorant of the effects and the costs of agricultural policies. Downs (1957) described the rationally ignorant voter in a situation where the benefits of. government interventions are concentrated but their costs are widely spread. The more diffuse is the incidence of the costs of the intervention, the less incentive there is for the individual voter to learn about that issue. The voter remains rationally ignorant. 
Brooks (1996, p.370) states that the assumption that voters are rationally ignorant is '...intuitively central to an understanding of why most OECD countries subsidise their farmers...'. The application of economics to politics has consistently produced the conclusion that the information flow in the democratic process is filtered and noisy when compared to the economic market (see inter alia Riker, 1982). Voting is infrequent, one vote encompasses a series of issues, and everyone votes not just those directly associated with the decision. In the economic market agents do not vote on matters of no particular interest to them. Further, information is relatively in an economic market. This kind of market is a superior mechanism for revealing sovereign preferences, because people feel the full cost and benefit of their decision (assuming there are no externalities). In a world of rationally ignorant voters, interest groups are the key actors in the political system. Through collective action they produce support for politicians and receive rent-creating interventions in return. In his model of interest groups, Becker (1983, p.372) notes 'voter preferences are not a crucial independent (author's italics) force in political behaviour'. Instead, it is the observation that farm interest groups are relatively more efficient (compared with other interest groups) at producing political pressure that explains the structure of agricultural policies in OECD countries.

De Gorter and Swinnen $(1994,1995)$ argue that the activities of interest groups are not a fundamental factor in determining the structure of agricultural policies across OECD countries. Voters are rational, self-interested and fully informed about agricultural policies, rather than rationally ignorant. An understanding of the nature of agricultural policies in the OECD requires an analysis of the interaction of political support-seeking politicians and support-supplying voters. The politician-voter link is more important than the politician-interest group link(1).

The second source of support for the interest groups framework has been the histories of state support for European agriculture including the CAP. These have emphasised the influence of interest groups as critical in understanding past policy decisions. Tracy (1989) and Milward (1992) trace the construction of a common agricultural policy in terms of the political influence of national farm groups. The history of UK agricultural policy from 1947 to 1973 is told in Self and Storing (1962), Smith (1990), and Tracy (1989) as the history of the political strength of the National Farmers Union (NFU).

These histories also detail a system of institutional arrangements set up to provide a regular and routine interface between the farm lobby and government. Institutions are highlighted as an important factor in explaining the persistent influence of farm interest groups. A basic assumption of the interest groups framework is that, '...the major farm policies survive because of the particular sets of institutions involved in the setting of policy and the structure of the decision framework which they operate, as well as the pressure from interest groups' (Moyer and Josling 1990, p.45).

Prominent interest groups enjoy the political power to influence decisions or in the limiting case to force decisions to be made or not made. However, an integral part of their influence is the privileged institutional access they enjoy. Their relationships with the institutions of the state are central to understanding agricultural policy. Institutions matter because they affect '...the structure, scope and character of activity by interest organisations' (Grant 1993, p.44).

Richardson and Jordan (1979) and Mazey and Richardson (1993) describe a policy community as having the following characteristics: membership is limited to a small number of state institutions and interest groups; the members interact frequently and across all aspects of policy; there is a high degree of consensus as to the means and ends of policy in the particular area covered by the 
community; the members regard power as a positive sum game, so that for each member their influence is maximised by being a member of the community as opposed to remaining outside it.

In terms of an agricultural policy community, the fact that a farm group's absolute political strength may have declined does not necessarily affect their influence, because they do not have to compete with other groups for government's attention and financial support. Schmitt (1986: 342) highlights the 'absence of effective checks restricting and repressing the unilateral influence and pressure of the agricultural sector'.

Any attempt to describe the CAP decision-making system as a policy community starts from the point that it will be more extensive and complex than the relationship between a national ministry and its national client groups (e.g. farm groups, food processors, agribusiness interests, environmental interests). Interest groups affected by the CAP are in a two-level game because they have two lobbying arenas; at the national level and the European level (Putnam 1988). The national level refers to the lobbying of member states' vote in the CoAM. The second refers to lobbying the Commission directly through membership of umbrella organisations, the most important of which is the Comité des Organisations Professionelles Agricoles (COPA). These two sets of relationships provide a wider policy community than those that exist in national policy arenas. The different strategies for the two levels of lobbying are discussed in Grant (1993) and Averyt (1977).

The literature on COPA provides the insight that COPA has a role in the bureaucratic functioning of the extant CAP system. It usually has $50 \%$ of the membership of the Commission's advisory, management and regulatory committees that exist for each of the CAP product regimes. Hence Smith (1990) states, 'COPA's relationship with DG VI is...very close'. Further, these different committees can sometimes take decisions of major political consequence. Blumann and Adam (1997) describe how the actions of the comitology committees of the CAP ignited the BSE crisis in March 1996.

However, Petit et al (1987), Tracy (1989), Moyer and Josling (1990), Mahé and Roe (1996), and Kay (1998) in presenting their evidence of the reforms of the CAP in the 1980s and 1990s do not give COPA any role at all. COPA was forced to react to a CAP reform agenda and was unable to agree a response to the proposals promulgated by the Commission in 1983, 1987, 1991 and 1997. It can therefore be inferred that COPA had very little influence on the outcome of those CAP reforms. If COPA has strong links with certain parts of DG VI and representation on the various committees of the Commission, this does not seem to have extended to having a position in any policy community on the issue of CAP reform. This conclusion leaves open the question of the extent to which agricultural policy interest groups can influence the behaviour of the relevant national ministry. This question is also central to the institutions framework so discussion of it is deferred to the next section.

\section{The institutions framework}

The central element of the institutions framework is that the institutional context of the pressures for CAP reform is important in understanding a CAP reform. The institutions of CAP decision-making rather than interest groups, are the transmission mechanisms from the pressures to reform the CAP to the enactment of certain CAP reforms at certain times. The position taken by national representatives 
in the CoAM on a CAP reform is a result of the institutional fact that they are ministers of agriculture and that supporting agriculture is their department's raison d'être. Institutional structures rather than the influence of interest groups determines agency behaviour.

Peterson (1995) charts the rise of a new institutionalism, 'EU institutions may develop their own agendas and act autonomously of allied interest groups' (Peterson, 1995, p.81). Interest groups will have access to these institutions, but this does not equate to genuine influence in a reform situation. This is not to argue that state institutions enacting agricultural policy do not wish to have the support of agricultural policy interest groups, rather the claim is that agricultural policy interest groups do not hold the resources necessary to influence or veto the CAP reform process.

For the institutions framework to be applied to the CAP decision-making system, it is not necessary to argue that a policy community does not exist. The term policy community was originally developed to argue that groups had significant resources and could limit the extent of state autonomy; the existence of a policy community was an illustration of a lack of state autonomy. Richardson and Jordan (1979) provide a detailed account of this view. However, Smith (1993) re-interprets the existence of policy communities as evidence of the autonomy of state institutions. The agenda of the policy community and the mediation of different views within it are dominated by state institutions. By establishing these communities with affected interest groups, state institutions actually increase their capacity to act autonomously.

The central institution of CAP decision-making is the CoAM. Fifteen agriculture ministers formally enact any CAP reform, hence all factors and mechanisms involved in the CAP reform process must be traced back from that point. Any account of a CAP reform should put the members of the CoAM into their political context (at both domestic and EU level). This will afford an understanding of their bargaining positions and 'domain of feasible compromise' (Petit et al 1987).

Formally, the Commission controls the agenda of the CoAM. It enjoys the sole right to propose legislation, and for the CoAM to agree something different from an initial Commission proposal requires unanimity or the consent of the Commission. Hence the Commission creates a reform situation by the proposal of reform. Peterson (1995) calls these 'meso-level' decisions. The ability to control the agenda is also the ability to affect the final policy outcome, even if the power of enactment exists elsewhere. The CAP reforms that are enacted are shaped by the reforms proposed.

These meso-level decisions are not the exclusive preserve of the Commission: there is the question of the circumstances in which the Commission will propose a reform, i.e. exercise the policy-shaping function. The decision to promulgate reform proposals must to some extent be based on a political calculation of what the CoAM will agree. Further, in the reforms of 1984 and 1988, the European Council was active in forcing a CAP reform agenda on the CoAM. It is clear from the CAP reform accounts in Petit et al (1987), Moyer and Josling (1988), Mahé and Roe (1996), and Kay (1998) that what motivated the proposal of CAP reforms by the Commission is not necessarily linked to what prompts the final enactment of reform by the CoAM or the European Council.

Bulmer and Wessels (1987) argue that the European Council has increasingly been forced into the role of 'Court of Appeal', as was the case in the reforms of 1984 and 1988, by failures in the EU decision-making system. They note the lack of a co-ordinating institution between various Councils. As public policies have become increasingly complex, they have traversed the functional divisions of the Councils, e.g. the spillover of agricultural policy issues into trade, foreign affairs and budget areas. The European Council does not co-ordinate - it has no regular agenda and does not allocate 
responsibilities among the various Councils. Instead, the various Councils engage in a series of 'turf battles' with each other with the issues of greatest contention pushed up to European Council level for resolution. This was not the case in reforms of 1992 and 1999 and poses a challenge for the development of a coherent theory of CAP reform.

When a factor is specified as a cause of a CAP reform it is necessary to state where and what the incidence of that factor is, in particular, how it affects the Commission, the Commission's calculations about the Council, and the Council. Further, the reform process is generally long (over a year for the reforms of 1984 and 1988 and nearly two years for 1992 and 1999) and decisions are made by different institutions at different times. Thus, even if it is claimed that same factor affects all institutions, it affects them at different times and in different circumstances.

CAP reforms start with the Commission and end with the CoAM. It is these two institutions which determine the characteristics of the reform process and the reform outcomes. The Commission provides part of the explanation of why the reform of the CAP tends to be drawn out and reforms incremental. DG II (Economics) and DG XIX (Budget) have wrestled (unsuccessfully) with DG VI for control of the CAP agenda. Further, the horizontal separation of DG VI by commodity division hampers the internal construction of reform proposals. Reforms are conceived in small groups and cliques away from the main policy or administrative channels of DG VI. The role of Commissioners' cabinets was a material factor in each of the reforms of the 1980s and 1990s.

The CoAM is pro-agriculture because its members are politicians who bring the perspective of incumbent ministers of agriculture. The influence of agricultural policy interest groups in policy-process is much less than the influence of this basic institutional fact. The source of explanation of CAP reform lies in why a qualified majority of members (at some time) are constrained to accept the inevitability of reform.

There are two ways to infer that the institutional context dominates the pressure of interest groups as a motivating factor in a national government's position on a proposed CAP reform. The first emphasises that each member of the CoAM is a member of a national government, which has to agree at an executive level a negotiating position for the minister of agriculture to adopt in the CoAM. Swinbank (1989), in a UK context, quotes Peter Walker from 1981 as saying that the Secretary of State for Agriculture never negotiates beyond his brief agreed with Cabinet (including the Chancellor of the Exchequer). Walker regarded the view of the CoAM as a group of agriculture ministers who push up farm prices, oblivious or indifferent to the effect on the EU budget as a 'great myth'.

Walker's point is that because the position taken in the CoAM has to be agreed collectively by each national government, this will constrain the ability of the CoAM to expand the budget of the CAP. The key institutional point is that the position taken in the CoAM is that of the UK government, and not the Ministry of Agriculture, Fisheries and Food (MAFF). Interest groups have to compete with other ministries and their client interest groups for control of the UK government's position on the CAP.

Petit et al (1987) and Moyer and Josling (1990) describe the existence of national agricultural policy 
communities including influential agricultural interest groups in both France and Germany. However, more recently Epstein (1997) and Von Cramon-Taubadel (1993) argue that the policy process for agriculture in France and Germany respectively can no longer be accurately described or analysed using the concept of a policy community. The evidence from policy towards the CAP and the GATT in the 1990s was that the access of traditionally powerful farm interest groups was no longer exclusive, there was no longer a broad and stable consensus on agricultural policy and, crucially, agricultural policy-making had become heavily politicised. Epstein (1997) explains this last point in terms of the end of 'programme sectorization', the situation where ministry officials and the principal unions could deal with a clearly circumscribed agricultural agenda without reference to the effect on other political or economic interests.

The need for each member state to allow their representative to 'play the CoAM game' allows a second inference that institutional context rather than interest group pressure is more important in determining the preferences of national representatives. The enactment of previous CAP reforms has not required the agreement of all fifteen member states. Instead, reforms have occurred when France and Germany have agreed on a set of proposals. In such circumstances, any other view of CAP reform will tend to get out-voted. The game of the CoAM is to maximise your view of the national agricultural interest in the context of the reform likely to be agreed upon by a qualified majority (usually including France and Germany). The dynamics of this political manoeuvring are beyond the influence or control of national interest groups. Even if they can influence a member states' initial bargaining position, it is unlikely that they can influence the compromise process as each member state seeks to maximise its payoff from the CAP reform package that is about to be agreed.

In this framework, members of the CoAM are pro-agriculture in the sense of defending the existing CAP system. This is the baseline against which any incumbent measures success at the job. To allow reform would be a surrender of what some earlier minister of agriculture (or themselves) had negotiated for their nation's farm interest. The surrender of the status quo is a political cost. This defensive posture means that the CoAM has been characterised as myopic (Petit et al 1987). Preserving the CAP, and their nation's pay-off, will tend to be the opening negotiating stance of each member of the CoAM.

\section{Conclusion}

The evidence of the last 15 years does not seem to support the inference that EU-level interest groups have had a significant influence on the reform of the CAP, either in terms of the timing or content of the reforms. Further, there is evidence that the influence of national farm groups on national governments in the CAP reform process is declining in important member states, such as France and Germany. Other interests, notably the pressure of international trade negotiations and the concomitant domestic business interest, have become more influential. This paper argues that the influence of institutions is a more appropriate inference from the evidence of the CAP reform process; the group of theories in the institutions framework explains a greater range of the observable facts than those theories in the interest groups framework.

The paper does not claim to have arrived at a theory of CAP reform. Instead, it suggests a direction for the development of such a theory. The criteria proposed by Thaggard (1992); explanatory breadth, simplicity, and analogy should guide the development a theory of CAP reform. The criterion of explanatory breadth captures the idea that a theory is a better explanation than its rivals are if it explains a greater range of facts. The notion of simplicity is captured by the idea that preference should be given to theories that make fewer special assumptions. Finally, explanations are judged 
more coherent if they are supported by analogy to theories that social scientists already find credible.

\section{References ${ }^{\star}$}

Ackrill, R.W., Hine, R.C., Rayner, A.J. and Suardi, M. (1994). The Distributional

Effects of the Common Agricultural Policy between Member states: Budget and Trade effects. CREDIT Research Paper, Department of Economics, University of Nottingham, Nottingham.

Averyt, W.F. (1977). Agropolitics in the European Community: Interest Groups and the CAP. Praeger: New York.

Becker, G.S. (1983). A theory of competition among pressure groups for political influence, Quarterly Journal of Economics, 98, 371-400.

Brooks, J. (1995). The Economic Polity of Farm Policy: A Comment, Journal of Agricultural Economics, 46, 398-402

Brooks, J. (1996). Agricultural Policies in OECD countries: what can we learn from political economy models?, Journal of Agricultural Economics, 47, 366-389

Bulmer, S. and Wessels, W. (1987). The European Council. London: Macmillan.

Blumann, C. and Adam, V. (1997). La Politique Agricole Commune dans la

Tourmente: La Crise de la 'Vache Folle', Revue Trimestrielle de Droit Européen, 2, 239-293.

Davey, B., Josling, T.E. and McFarquhar, A.(ed.) (1976). Agriculture and the State. London: MacMillan.

Downs, A. (1957). An Economic Theory of Democracy. New York: Harper and Row.

Egdell, J.M. and Thomson, K.J. (1999). The Influence of UK NGOs on the Common Agricultural Policy, Journal of Common Market Studies, 37(1), 121-131.

Epstein, P.J. (1997). Beyond Policy Community: French Agriculture and the GATT, Journal of European Public Policy, 4(3), 355-372.

Field, H., Hearn, S. and Kirby, M.G. (1989). The 1988 EC Budget and Production Stabilisers. Australian Bureau of Agricultural and Resource Economics Discussion Paper.

de Gorter, H. and Swinnen, J. (1994). The Economic Polity of Farm Policy, Journal of Agricultural Economics, 45, 312-326.

de Gorter, H. and Swinnen, J. (1995). The Economic Polity of Farm Policy: A Reply, Journal of Agricultural Economics, 46, 403-414.

Grant, W. (1993). Pressure Groups and the European Community: an overview. In Mazey, S. and J.J. Richardson (eds), Lobbying in the European Community. Oxford: OUP. 
Hirschman, A.O. (1970). Exit, Voice and Loyalty: Responses to Declines in Firms, Organizations and States. Cambridge, Mass.: Harvard University Press.

Hull, R. (1993). Lobbying Brussels: A View from Within, in Mazey, S. and Richardson, J. (eds.) Lobbying in the European Community. Oxford: Oxford University Press.

Kay, A. (1998). The Reform of the CAP: The Case of the MacSharry Reforms. Wallingford: CABI International.

Kinach, B. (1996). Grounded Theory as Scientific Method: Haig-Inspired Reflections on Educational Research Methodology. Philosophy of Education Society, Illinois, [http://www.ed.uiuc.edu/PES/95_docs/kinach.html].

Koester, U. (1978). Decision-making Problems in the Council of Agriculture Ministers, Intereconomics, 9, 211-215.

Mahé, L.P and Toe, T.L. (1996). The Political Economy of Reforming the 1992 CAP Reform, American Journal of Agricultural Economics, 78, 1314-1323.

Marsh, D. and Rhodes, R.A.W. (1992). Policy Networks in British Government. Oxford: OUP.

Mazey, S. and Richardson, J.J. (eds) (1993). Lobbying in the European Community. Oxford: OUP.

Milward, A. (1992). The European rescue of the nation-state. London: Routledge.

Moyer, H.W. and Josling, T.E. (1990). Agricultural Policy Reform: Politics and Process in the EC and USA. Hemel Hempstead: Harvester Wheatsheaf.

Olson, M. (1965). The Logic of Collective Action. Cambridge: Harvard University Press.

Peterson, J. (1995). Decision-making in the European Union: towards a framework for analysis, Journal of European Public Policy, 1, 69-95.

Putnam, R.D. (1988). Diplomacy and Domestic Politics: the Logic of Two-Level Games, International Organization, 42, 428-460.

Richardson, J.J. and Jordan, A.G. (1979). Governing Under Pressure: the Policy Process in a Post-parliamentary Democracy. Oxford: Martin Robertson.

Schmitt, G. (1986). Agricultural Policy Decisions in the EC, Food Policy, 5, 334-345.

Self, P. and Storing, H. (1962). The State and the Farmer. London: Allen\&Unwin.

Smith, M.J. (1990). The Politics of Agricultural Support in Britain. Aldershot: Dartmouth.

Smith, M.J. (1993). Pressure, Power and Society. Hemel Hempstead: Harvester Wheatsheaf.

Stigler, G.J. (1975). The Citizen and the State. Chicago: University of Chicago Press.

Swinbank, A. (1989). The CAP and the Politics of European Decision Making, Journal of Common Market Studies, 2, 303-322.

Thaggard, P. (1992). Conceptual Revolutions. Princeton: Princeton University Press. 
Tracy, M. (1989). Government and Agriculture in Western Europe 1880-1988, 3rd ed. London: Granada.

Von Cramon-Taubadel, S. (1993). The Reform of the CAP from a German Perspective. Journal of Agricultural Economics, 44, 394-409.

\section{Endnotes}

(*) The author would like to thank the two anonymous referees of the EIoP for their comments.

(1) This paper considers the influence of state institutions as an alternative to interest group influence on CAP decisions. Both may influence public opinion but it is difficult to disentangle empirically this effect from any independent effect of public opinion. Further, whilst there is some evidence of interest group influence on CAP decisions there seems to be no evidence of public opinion having an effect. Therefore, the politician-voter link is ignored in this paper. 